\title{
Identification of Transferred Chicken Germ Cells in Quail Gonad and Semen by Amplification of Chicken-Specific PCR Products
}

\author{
Hai-Chang $\mathrm{Li}^{1,2)}$, Li Zhao ${ }^{3)}$, Hiroshi Kagami ${ }^{2)}$, Kanji Matsui ${ }^{2)}$ \\ and Tamao $\mathrm{Ono}^{2), *}$ \\ 1) United Graduate School of Agricultural Science, Gifu University, Gifu 501-1193, Japan \\ ${ }^{2)}$ Faculty of Agriculture, Shinshu University, Minamiminowa, Nagano 399-4598, Japan \\ 3) Genomic Sciences Center, The Institute of Physical and Chemical Research
} (RIKEN), Wako, Saitama 351-0106, Japan

\begin{abstract}
A polymerase chain reaction (PCR) primer set for a chicken microsatellite locus on the $\mathrm{Z}$ chromosome, LEI0171 (GenBank Accession No. X85538), amplified a $363 \mathrm{bp}$ fragment of genomic DNA in chickens (Gallus domesticus) but not in quail (Coturnix japonica). A concentration of at least $10 \mathrm{pg} / \mu l$ of chicken DNA in the reaction mixture resulted in detectable amplification of the PCR product. Circulating primordial germ cells (PGCs) of chick embryos were transfused into quail embryos, and the chickengenome-specific PCR product was observed in the chick-PGC-transfused chimeric quail when DNA samples were extracted from whole day- 6 embryos, day- 10 and -15 embryonic gonads, gonads of 5-day chicks, and the semen of adults.
\end{abstract}

Key words : microsatellite DNA ; chicken ; PCR ; primordial germ cells ; quail

\section{Introduction}

Primordial germ cells (PGCs) are the first identifiable progenitors of gametes and provide the only cellular continuity between generations. Unlike the PGCs in amphibians and mammals, PGCs in birds and reptiles migrate primarily by means of the bloodstream (Gilbert, 2000).

Recently, interspecific transfers of circulating PGCs have been attempted from turkeys to chickens (Reynaud, 1976), chickens to quail (Yasuda et al., 1992 ; Ono et al., 1998 b) and quail to chickens (Ono et al., 1996 ; Ono et al., 1998 a). If the transferred PGCs differentiate into functional gametes in the gonadal tissue of the recipient birds, offspring of the donor bird's species could be recovered by mating of germline chimeras. Thus, transfer of PGCs could play an important role in the preservation of endangered species (Tajima et al., 1993,1998 ; Naito et al., 1994 ; Fujihara et al., 1999).

In order to identify the interspecifically transferred germ cells in the recipient animals, reliable markers that can distinguish between cells of exogenous and endogenous origin are required. We have evaluated 3 monoclonal antibodies (mAbs), QCR 1, QB2 and 2C9, for their ability to distinguish between chicken and quail PGCs in

Received : May 17, 2001 Accepted : June 13, 2001

* Corresponding author. Tel/Fax : +81-26577-1434 ; e-mail : tamaoon@gipmc.shinshu-u.ac.jp 
chimeric embryos (Ono et al., $1996 ; 1998 \mathrm{ab}$ ). QCR1 and QB2 are quail-specific $\mathrm{mAbs}$ and $2 \mathrm{C} 9$ is a chick-specific $\mathrm{mAb}$ showing developmental-stage-specific staining. These mAbs unfortunately did not label germ cells in adult testicular tissues and spermatozoa (Ono et al., 1998 a). We were able to show that transfused quail PGCs settled in the gonads of chick embryos and hatchlings ; however, we failed to detect donor-derived offspring born from interspecific germline chimeras (Ono et al., $1998 \mathrm{a}$ ).

A polymerase chain reaction (PCR) primer set that distinguished between DNA of donor-derived germ cells and that of recipient cells would be useful as well as convenient for obtaining direct evidence that interspecifically transferred germ cells are present in the recipient animals. Sexing can be performed by PCR using a primer set which amplifies a W chromosome-specific DNA sequence (Clinton, 1994 ; Petitte and Kegelmeyer 1995 ; Simkiss et al., 1996). In the present study, isolated chick PGCs were transferred into quail embryos, and the chimeric quail were raised to sexual maturity. We developed a system that distinguishes between donor chicken and recipient quail genomes by means of PCR, and we used this system to identify donor chicken-derived germ cells in the recipient quail.

\section{Materials and Methods}

\section{Animals}

Fertilized eggs of wild-type plumage strains of Japanese quail (Coturnix japonica) maintained in our laboratory and those of White Leghorn (Aichi-line) chickens (Gallus domesticus) obtained from Aichi Livestock and Poultry Breeding Center (Anjo) were used throughout the study. Incubation of eggs was done under normal conditions ( $\mathrm{Li}$ et al., $2001 \mathrm{a}$ ) and the staging of embryonic development was determined using the standards of Hamburger and Hamilton (1951).

\section{Transfer of chick PGCs to quail embryos}

Chick embryonic blood was collected according to a previously reported protocol (Li et al., 2001 a). PGCs were enriched by Ficoll density gradient centrifugation as described by Yasuda et al. (1992) with minor modifications. Briefly, pooled blood was dispersed in medium FCS/L15 (Leibovitz's L-15 medium (Sigma Chemical Co., St. Louis, MO) containing 10\% fetal calf serum (FCS, Nippon Bio-Test Lab. Inc., Tokyo)), and centrifuged at $200 \mathrm{G}$ for 3-5 min. The pellet was then dispersed in 250-300 $\mu \mathrm{l}$ of $5.0 \%$ Ficoll (F9378, Sigma Chemical Co.) in FCS/L15, and overlaid on $800 \mu \mathrm{l}$ of $16.0 \%$ Ficoll in FCS/L15. After centrifugation at $800 \mathrm{G}$ for $25 \mathrm{~min}, 400-600 \mu \mathrm{l}$ of the PGC-rich fraction located in the layer between $16.0 \%$ and $5.0 \%$ Ficoll was collected and dispersed in $1000 \mu \mathrm{l}$ of FCS/L15, and Ficoll was removed by repeated centrifugation at $200 \mathrm{G}$ for $5 \mathrm{~min}$. The concentration of the PGCs was estimated using a haemocytometer viewed under a phase contrast microscope, and a suspension of 150$200 \mathrm{PGCs} / \mu l$ in FCS/L15 was obtained.

Quail embryos at stage 14-15 were used as recipients. To reduce the number of endogenous PGCs, some embryos were exposed to soft X-rays (Li et al., 2001 b). The irradiated embryos were cultured at $37.6^{\circ} \mathrm{C}$ and $70 \%$ relative humidity without tilting for about $1 \mathrm{hr}$ prior to PGC-injection. 
One microliter of chick PGC suspension (150-200 PGCs) was transfused into the marginal vein of the quail embryo and the perforation was sealed according to the method described by Yasuda et al. (1992). The transfused embryos were cultured in vitro in System Q3 (Ono et al., 1994) until day 6, 10, or 15 of incubation, or until hatching.

\section{Preparation of genomic DNA}

Genomic DNA samples of chick PGC-transfused quail were extracted from whole day-6 embryos, gonadal tissues of day-10 and -15 embryos and 5-day chicks, semen of adult males, and from the epididymis and/or vas deferens from dead chimeras. DNA samples were also extracted from blood and semen of normal chickens and quail. The DNA was extracted using a DNeasy Tissue Kit (Qiagen, Tokyo) according to the manufacturer's instructions or using phenol-chloroform (Ausubel et al., 1999). The DNA concentration was determined spectrophotometrically at $260 \mathrm{~nm}$.

Identification of chicken germ cells in quail

Information about the primer sequences was obtained from the web site of the US Poultry Genome Project (http : //poultry.mph.msu.edu/resources/ms-tot.htm). To distinguish between chicken and quail genomic DNA by PCR, a primer set for microsatellite locus LEI0171 (GenBank Accession No. X85538) on the Z chromosome (Schmid et al., 2000) was used. The LEI0171 primer sequences 5'GAGTGTAGACAGTAGTGTATC-3' and 5'-CTCAGGGCACCATTTTCACTG-3' were used as forward and reverse primers, respectively. The PCR was performed in a $25-\mu 1$ mixture consisting of $0.25-25 \mathrm{ng}$ of DNA template, $2.5 \mu \mathrm{l}$ of $10 \mathrm{X} \mathrm{Ex} \mathrm{Taq}^{\mathrm{TM}}$ buffer $^{2}$ ; $2 \mu l$ of dNTP mixture $(2.5 \mathrm{mM}$ each), each primer at $0.25 \mu \mathrm{M}, 0.075$ units of EX Taq $^{\text {TM }}$ (TaKaRa EX Taq ${ }^{\text {TM }}$ PCR kit, Takara, Tokyo) with 32 cycles of denaturation at $94^{\circ} \mathrm{C}$ for $30 \mathrm{sec}$, annealing at $56.5^{\circ} \mathrm{C}$ for $30 \mathrm{sec}$ and extension at $72^{\circ} \mathrm{C}$ for $30 \mathrm{sec}$, with a preliminary denaturation at $94^{\circ} \mathrm{C}$ for $5 \mathrm{~min}$ and a final extension at $72^{\circ} \mathrm{C}$ for $5 \mathrm{~min}$ using a PC-801 Program Temp Control System (Astec, Fukuoka). Ten microliters of the PCR mixture were electrophoresed on a $1.5 \%$ agarose gel. The gel image was scanned (GT-9500, Epson, Tokyo) and the signal of the PCR products was enhanced with Photoshop software (Adobe Systems, Inc., Tokyo) to examine faint bands. The PCR products taken from Aichi-line chickens ( 1 female and 2 males) were sequenced using a model 377 automated DNA sequencer (ABI, Chiba).

Statistical analysis

Data were analyzed statistically with chi-square test (Snedecor and Cochran, 1989). Differences were regarded as significant at $\mathrm{p}<0.05$.

\section{Results}

We first examined the PCR products amplified from DNA samples extracted from chicken and quail blood (Fig. 1). Genomic DNA of male and female quail was not amplified with this primer set under these condition. By contrast, that of male and female chickens was amplified. At $10 \mathrm{pg} / \mu l$ or higher concentrations, chicken DNA was amplified to a detectable level. The PCR product was also detectable when chicken DNA was mixed with quail DNA. Fig. 2 shows the nucleotide sequence of 


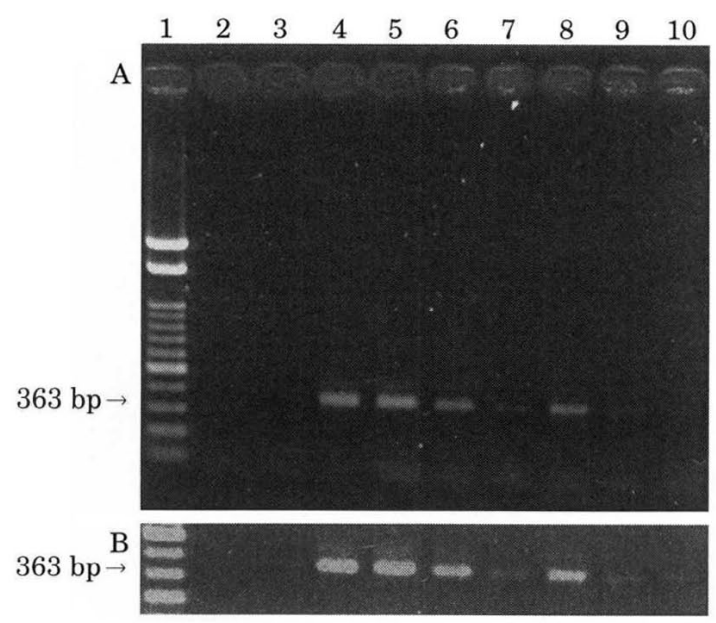

Fig. 1. Fragments produced after 32 cycles of PCR amplification of DNA from the blood of quail and chickens. Ten microliters of PCR products were applied to the gel. PCR conditions are described in the text. Lanes : 1, $100 \mathrm{bp}$ ladder molecular size marker ; 2 , female quail $(1 \mathrm{ng} / \mu l)$. Numbers in parenthesis indicate the concentration of the DNA template in a $25-\mu l$ PCR mixture ; 3 , male quail ( $1 \mathrm{ng}$ / $\mu l)$; 4 , female chicken $(1 \mathrm{ng} / \mu l) ; 5$, male chicken $(1 \mathrm{ng} / \mu l) ; 6$, male chicken $(100 \mathrm{pg} / \mu l) ; 7$, male chicken $(10 \mathrm{pg} / \mu l) ; 8$, mixed DNA consisting of male chicken $(100 \mathrm{pg} / \mu \mathrm{l})$ and male quail $(900 \mathrm{pg} / \mu \mathrm{l})$ DNA ; 9 , mixed DNA consisting of male chicken $(10 \mathrm{pg} / \mu l)$ and male quail $(990 \mathrm{pg} / \mu \mathrm{l})$ DNA ; 10 , mixed DNA consisting of male chicken $(10 \mathrm{pg} / \mu l)$ and male quail $(1 \mathrm{ng} / \mu l)$ DNA. B is an enhanced image of A processed with Adobe Photoshop.

\footnotetext{
1 CTCAGGGCAC CATTTTCACT GgTATAAgCA tATCAgCACT TAATCTATgT

51 ATAAGgAgtA CTATGGGGCT CTTTAGGACA ACTCACACTT CAACCACAAA

101 AACACATTCA TTtAGCAGCT GTTGTTACAT AAAAGCGAAC TGTTTTAATT

151 TAATGAAAAC ACAAATAAAA ACATATTACA TTATGCAACT GTGTTTTTCA

201 TTAAAATGTA CCTGATGTAC ACACACACAC ACACACACAC ACACACACAC

251 ACACACACAA AAAGTGGTGA AAATTGGCTG TATATGCTAA GCTAATTTAA

301 GTGTTGCAAA AATGTAAAAT ATCTTGTAAC TGCCTTCATA TTGATACACT

351 ACTGTCTACA CTC
}

Fig. 2. Nucleotide sequence of the amplified region of microsatellite locus LEI0171 on the $Z$ chromosome in Aichi-line chickens. Underlined sequences are the primer regions.

the amplified region of the chicken DNA. All three samples had identical 363-bp sequences.

We next examined the PCR products of DNA samples extracted from gonadal 


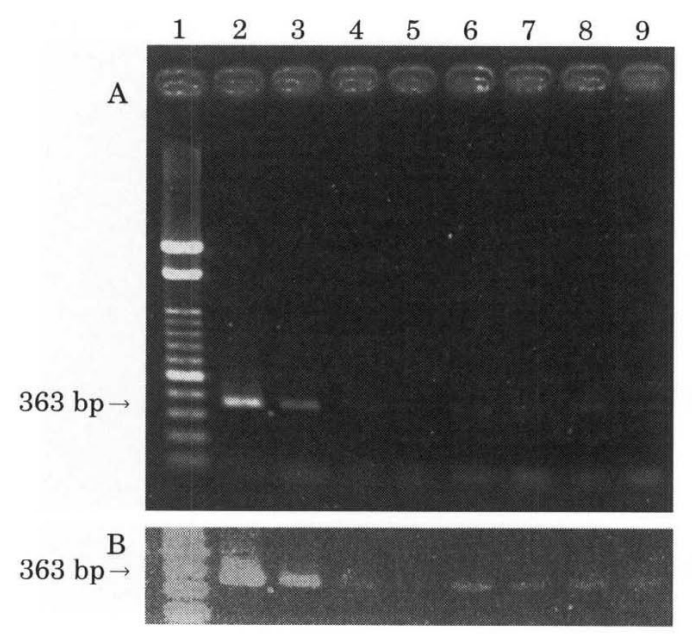

Fig. 3. Fragments produced after 32 cycles of PCR amplification of gonadal DNA from chick-PGC-transfused quail. Ten microliters of PCR products were applied to the gel. PCR conditions are described in the text. Lanes: 1, $100 \mathrm{bp}$ ladder molecular size marker; 2, day-10 chick embryo $(1 \mathrm{ng} / \mu l)$. Numbers in parenthesis indicate the concentration of the DNA template in a $25-\mu l$ PCR mixture; 3, day-10 chick embryo $(100 \mathrm{pg} / \mu l) ; 4$, day-10 chick embryo $(10 \mathrm{pg} / \mu l) ; 5$, day-10 quail embryo $(1 \mathrm{ng} / \mu l) ; 6$, day6 chick-PGC-transfused quail embryo ( $1 \mathrm{ng} / \mu l$, whole embryo) ; 7 , day-10 chick-PGC-transfused quail embryo $(1 \mathrm{ng} / \mu l) ; 8$ and 9 , day15 chick-PGC-transfused quail embryo $(1 \mathrm{ng} / \mu l)$. B is an enhanced image of A processed with Adobe PhotoShop.

tissues of chick PGC-transfused quail (Fig. 3). Amplified products were detected for DNA from whole day-6 embryos, gonadal tissues of day-10 and -15 embryos and 5-day chicks (Figs. 3 and 4). The intensity of the signal in chimeric embryos was roughly one-hundredth of that in chick embryos.

Table 1 shows the hatchability of manipulated quail embryos. When quail embryos at stage 14-15 were cultured using System Q3, 41.8\% of them hatched. Manipulation by irradiation, introduction of chick PGCs or both caused reduced hatchabilities of $23.1 \%, 20.5 \%$ and $11.7 \%$, respectively.

Finally we examined the PCR products of DNA samples extracted from the semen of chick PGC-transfused quail. The expected PCR products were amplified from DNA extracted from the semen of chimeras (Fig. 4). The intensity of the signal in semen of chimeras was between one-hundredth and one-tenth of that in semen of chickens. The 363-bp band was also amplified from the DNA samples extracted from the vas deferens and epididymis of chimeras (data not shown).

Table 2 shows the fraction of chick-PGC-transfused quail that expressed the PCR products of the chicken-specific DNA. At all stages examined, germ cell chimeras were observed in the irradiated and non-irradiated groups, but there was no significant difference between the two groups. 
Table 1. Hatchability of cultured embryos exposed to soft X-rays and/or injected with chick PGCs

\begin{tabular}{lccc}
\hline \multirow{2}{*}{ Type of treatment } & \multicolumn{2}{c}{ No. of embryos } & \\
\cline { 2 - 3 } & Cultured & Hatched & \\
\cline { 2 - 3 } None & 134 & 56 & $41.8 \%^{\mathrm{a}}$ \\
X & 104 & 24 & $23.1 \%^{\mathrm{b}}$ \\
FCS/L15 & 95 & 27 & $28.4 \%^{\mathrm{bc}}$ \\
PGC & 151 & 31 & $20.5 \% \%^{\text {bcd }}$ \\
X \& FCS/L15 & 42 & 7 & $16.7 \%^{\text {bcde }}$ \\
X \& PGC & 394 & 46 & $11.7 \%^{\mathrm{e}}$ \\
\hline
\end{tabular}

Embryos were transferred into System Q3 at stage 14-15 prior to the treatment.

$\mathrm{X}$, exposed to soft X-rays for $40 \mathrm{sec}$ at stage $14-15 ; \mathrm{FCS} / \mathrm{L} 15$, injected with $1 \mu \mathrm{l}$ of $10 \%$ fetal calf serum in Leibovitz's L-15 medium ; PGC, injected with $1 \mu l$ of chick PGC suspension in FCS/L15 (150-200 PGCs/ $/ \mu l)$. The hatchabilities marked with different letters are significantly different based on chi-square test $(\mathrm{P}<0.05)$.

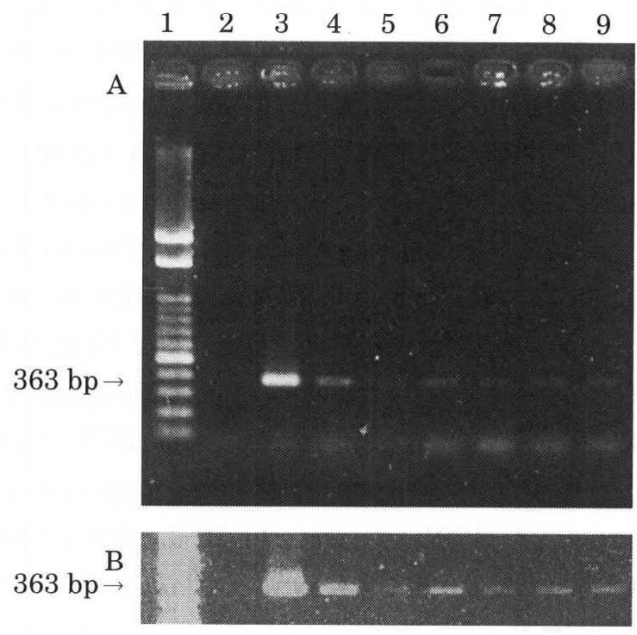

Fig. 4. Fragments produced after 32 cycles of PCR amplification of semen and gonadal DNA from chick-PGC-transfused quail. Ten microliters of PCR products were applied to the gel. PCR conditions are described in the text. Lanes: $1,100 \mathrm{bp}$ ladder molecular size marker; 2, quail $(1 \mathrm{ng} / \mu l) ; 3$, chicken $(1 \mathrm{ng} / \mu l)$. Numbers in parenthesis indicate the concentration of the DNA template in a $25-\mu l$ PCR mixture; 4, chicken $(100 \mathrm{pg} / \mu l) ; 5$, chicken $(10 \mathrm{pg} / \mu l) ; 6$ and 7 , gonadal tissue of 5 -day-old chick-PGC-transfused male quail $(1 \mathrm{ng} / \mu l) ; 8$ and 9 , semen of chick-PGC-transfused quail $(1 \mathrm{ng} / \mu l)$. B is an enhanced image of A processed with Adobe PhotoShop. 
Table 2. The incidence of chicken-specific fragments in DNA from chimeric quail

\begin{tabular}{ccccccc}
\hline \hline $\begin{array}{c}\text { Types of } \\
\text { treatment }\end{array}$ & $\begin{array}{c}\text { Day 6 } \\
\text { embryo }\end{array}$ & $\begin{array}{c}\text { Day 10 } \\
\text { embryo }\end{array}$ & $\begin{array}{c}\text { Day 15 } \\
\text { embryo }\end{array}$ & $\begin{array}{c}5 \text {-day } \\
\text { chick }\end{array}$ & $\begin{array}{c}\text { Adult } \\
\text { male }\end{array}$ & Total $^{1{ }^{1}}$ \\
\hline \multirow{2}{*}{ None } & $40 \%$ & $40 \%$ & $40 \%$ & $43 \%$ & $25 \%$ & $39 \%$ \\
& $(2 / 5)$ & $(2 / 5)$ & $(6 / 15)$ & $(3 / 7)$ & $(1 / 4)$ & $(14 / 36)$ \\
X-rays & $50 \%$ & $57 \%$ & $63 \%$ & $63 \%$ & $33 \%$ & $53 \%$ \\
& $(3 / 6)$ & $(4 / 7)$ & $(10 / 16)$ & $(5 / 8)$ & $(4 / 12)$ & $(26 / 49)$ \\
\hline
\end{tabular}

Numbers in parenthesis are expressed as no. of chimeras with amplified chicken genomic band per no. of chimeras observed. Genomic DNA samples of chick-PGC-transfused quail were extracted from whole day-6 embryos, gonadal tissues of day-10 and -15 embryos and 5-day chicks, and semen of adult males.

1) There was no significant difference based on chi-square test.

\section{Discussion}

We surveyed a number of primer sets originally designed for microsatellite loci of the chicken genome which were described in the web site of the US Poultry Genome Project. Among them we found that the primer set for microsatellite locus LEI0171 on the Z chromosome (GenBank Accession No. X85538; Schmid et al., 2000) amplified a fragment of $363 \mathrm{bp}$ in chicken (Aichi-line) genomic DNA but not in quail genomic DNA. This locus contains a polymorphic CA repeat region, and thus the length of the PCR product vary from 350 to 365 depending on the chicken line or breed (see web site at http : //poultry.mph.msu.edu/resources/ms-tot.htm).

In the present study, this primer set was able to amplify the donor-chicken-derived DNA in the chimeric quail. A concentration of at least $10 \mathrm{pg} / \mu l$ of chicken DNA in the PCR mixture was needed to detect the chicken-genome-specific band. The amount of DNA required would be reduced if a more sensitive PCR protocol and/or a more efficient primer set were available. A number of species-specific primer sets have been reported in poultry (Levin et al., 1995 ; Liu et al., 1996 ; Inoue-Murayama et al., 1998 ; Pang et al., 1999 ; Huang et al., 1999 ; Kayang et al., 2000) and these primers are candidates for our purposes. In the present study, the intensity of the chicken-DNAspecific signal in the gonads of chimeras was roughly one-hundredth of that in the gonads of chickens. This may be an over-estimation because a considerable amount of the recipient's somata was included in chimera's DNA samples, and the PCR protocol used was not designed for quantitative analysis. In our previous report we showed that $5.6 \%$ of gonadal PGCs were of donor chick origin in the chick-PGC-transfused quail embryos at stage 29 (Ono et al., 1998 b). Semen consists of sperm, their precursor cells such as spermatids and spermatocytes, and seminal fluid, so that DNA samples extracted from the semen of chimeric quail are mainly derived from sperm and their precursor cells. Therefore, it is likely that the population of donor-derived germ cells is roughly between $1 \%$ and $10 \%$ of total cells in the semen of chimeras. As yet no information about whether these donor-derived germ cells are functional sperm or not.

In conclusion, we found that the PCR primer set used in this study provided an 
excellent marker for distinguishing between chicken and quail DNA in chimeras, and with this marker we were able to show interspecific germ cells in the chimeras' semen.

\section{Acknowledgments}

This study was supported in part by Grants-in-aid for Scientific Research from the Ministry of Education, Science, Sports and Culture, Japan to H.K. (No. 13760193) and T.O. (No. 13460132).

\section{References}

Ausubel FM, Brent R, Kingston RE, Moore DD, Seidman JG, Smith JA and Struhl K. Short Protocols in Molecular Biology, 4th ed. John Wiley \& Sons, Inc. New York. 1999.

Clinton MA. A rapid protocol for sexing chick embryos (Gallus g. domesticus). Animal Genetics, $25: 361-362.1994$.

Fujihara N. Poultry genetic resources and conservation biology. Japanese Poultry Science, 36 : 127-147. 1999.

Gilbert SF. Developmental Biology, 6th ed. Sinauer Associates, Inc. Publishers. Sunderland, MA. 2000.

Hamburger $\mathrm{V}$ and Hamilton HL. A series of normal stages in the development of the chick embryo. Journal of Morphology, $88: 49-92.1951$.

Huang HB, Song YQ, Hsei M, Zahorchak R, Chiu J, Teuscher C and Smith EJ. Development and characterization of genetic mapping resources for the turkey (Meleagris gallopavo). Journal of Heredity, $90: 240-242.1999$.

Inoue-Murayama M, Nomura A, Ide H, Kimura K, Tatsuda K, Takahashi H, Nagamine Y, Hanada H, Takeda T, Tsudzuki M and Ito S. Application of chicken microsatellite markers to Japanese quail and Chinese painted quail. Animal Genetics, 29 (suppl 1) : 46.

Kayang BB, Inoue-Murayama M, Nomura A, Kimura K, Takahashi H, Mizutani M and Ito S. Fifty microsatellite markers for Japanese quail. Journal of Heredity, 91 : 502-505. 2000.

Li HC, Matsui K and Ono T. Population of circulating primordial germ cells in early Japanese quail embryos. Journal of Poultry Science, $28: 175-180.2001$ a.

Li HC, Kagami H, Matsui K and Ono T. Restriction of proliferation of primordial germ cells by the irradiation of Japanese quail embryos with soft X-rays. Comparative Biochemistry and Physiology Part A, 130 : 133-140. 2001 b.

Levin I, Chen HH, Baxter-Jones C and Hillel J. Turkey microsatellite loci amplified by chicken-specific primers. Animal Genetics, $26: 107-110.1995$.

Liu Z, Croojimans RPMA, van der Poel JJ and Groenen MAM. Use of chicken microsatellite markers in turkey : a pessimistic view. Animal Genetics, 27 : 191-193. 1996.

Naito M, Tajima A, Yasuda Y and Kuwana T. Preservation of chick primordial germ cells in liquid nitrogen and subsequent production of viable offspring. Journal of Reproduction and Fertility, $102: 321-325.1994$.

Ono T, Murakami T, Mochii M, Agata K, Kino K, Otsuka K, Ohta K, Mizutani M, Yoshida M, and Eguchi G. A complete culture system for avian transgenesis, supporting quail embryos from the single-cell stage to hatching. Developmental Biology, 161 : 126-130. 1994.

Ono T, Yokoi R and Aoyama $\mathbf{H}$. Transfer of male or female primordial germ cells of quail into chick embryonic gonads. Experimental Animals, 45 : 347-352. 1996.

Ono T, Yokoi R , Maeda S, Nishida T and Aoyama H. Settlement of quail primordial germ cells in chicken gonads. Animal Science and Technology, $69: 546-555.1998$ a.

Ono T, Yokoi R, Maeda S, Nishida T and Aoyama H. Transfusion of chick primordial germ cells into quail embryos and their settlement in gonads. Animal Science and Technology, 69 : 911-915. 1998 b.

Pang SW, Ritland C, Carlson JE and Cheng KM. Japanese quail microsatellite loci amplified with chicken-specific primers. Animal Genetics, 30 : 195-199. 1999.

Petitte JN and Kegelmeyer AE. Rapid sex determination of chick embryos using the polymerase 
chain reaction. Animal Biotechnology, $6: 119-130.1995$.

Reynaud, G. Capacites reproductricés et descendance de Poulets ayant subi un transfert de cellules germinales primordiales durant la vie embryonnaire. Roux's Archives of Developmental Biology, 79 : 85-110. 1976.

Schmid M, Nanda I, Guttenbach M, Steinlein C, Hoehn M, Schartl M, Haaf T, Weigend S, Fries R, Buerstedde JM, Wimmers K, Burt DW, Smith J, A'Hara S, Law A, Griffin DK, Bumstead N, Kaufman J, Thomson PA, Burke T, Groenen MA, Crooijmans RP, Vignal A, Fillon V, Morisson M, Pitel F, Tixier-Boichard M, Ladjali-Mohammedi K, Hillel J, Maki-Tanila A, Cheng HH, Delany ME, Burnside $\mathbf{J}$ and Mizuno S. First report on chicken genes and chromosomes 2000. Cytogenetics and Cell Genetics, $90: 169-218.2000$.

Simkiss K, Luke G and Behnam J. Female chromosomes in cockerel ejaculates. Proceedings of the Royal Society of London, B, $263: 1245-1249.1996$.

Snedecor WS and Cochran WG. Statistical Methods, Eighth ed. Iowa State Univ. Press. Ames, Iowa. 1989.

Tajima A, Naito M, Yasuda Y and Kuwana T. Production of germ line chimera by transfer of primordial germ cells in the domestic chicken (Gallus domesticus). Theriogenology, 40 : 509-519. 1993.

Tajima A, Naito M, Yasuda Y and Kuwana T. Production of germ-line chimeras by transfer of cryopreserved gonadal primordial germ cells (gPGCs) in chicken. Journal of Experimental Zoology, $280: 265-267.1998$.

Yasuda Y, Tajima A, Fujimoto T and Kuwana T. A method to obtain avian germ-line chimeras using isolated primordial germ cells. Journal of Reproduction and Fertility, $96: 521-528$. 1992. 